\title{
Time to up the game? Middle Eastern security and Chinese strategic involvement
}

\author{
Hai Yang ${ }^{1}$
}

(C) Springer-Verlag GmbH Germany, part of Springer Nature 2018

\begin{abstract}
In view of the resources invested by China in the Belt and Road Initiative (BRI) and the geopolitical-security dynamics at play, it is helpful to examine the notable security risks and uncertainties of the project. Embedded in this broad context, the paper at hand zooms in on one of the world's most volatile regions - the Middle East, situated strategically at the juncture of the overland and seaborne routes. Substantively, it focuses on the security dynamics in the region and China's current engagement therein, with a view to assessing whether and the extent to which China will boost its strategic presence in the BRI context. Some conclusions can be drawn from the research. First, the Middle East faces a multiplicity of security risks and challenges, compounded by a problematic existing security architecture based on inadequate cooperation among regional actors and questionable ad hoc interventions by major outside powers. Second, China's current relations in Middle Eastern countries have been overwhelmingly economic and driven by energy. Its political-security presence, albeit growing, remains marginal. Third, given the imperatives for China to play a more substantial role in Middle Eastern security (not least the need to ensure the BRI's security) and the risks/costs of doing so, it would make sense that China seeks to step up its game in areas that are conductive to stabilising the region and yet do not entail intensively investing strategic resources and publicly taking sides (e.g. infrastructure and conflict mediation). This offers reasonable prospect of further EU-China cooperation.
\end{abstract}

Unveiled in late 2013, the Belt and Road Initiative (BRI) has since then become a centrepiece in Chinese foreign policy under President Xi Jinping. The grandiose project consists of a land-based Belt and an ocean-going Road, supposedly connecting China

Hai Yang

hai.yang@kuleuven.be

1 Leuven International and European Studies Institute, University of Leuven (KU Leuven),

Parkstraat 45, box 3602, 3000 Leuven, Belgium 
to a wide range of countries across Asia, Europe, and Africa. As an overarching and long-term framework, it incorporates, beyond infrastructure and connectivity, tradeinvestment facilitation, financial integration, policy coordination, and people-to-people exchange (Chinese State Council 2015). At the first Belt and Road Forum in 2017, Xi (2017) pledged a total of RMB780 billion (approximately $\$ 120$ billion) in funding to support BRI projects. As of August 2017, 69 countries and international organisations had inked BRI cooperation agreements with China (Chinese National Development and Reform Commission 2017). While speculations abound about the underlying motives and considerable ramifications of the potentially game-changing initiative (Cheng 2016; Clarke 2017; Ferdinand 2016; Huang 2016; Rolland 2017; Wang 2016; Yu 2017), one thing seems certain — the BRI is anything but a purely economic project.

Clearly, the far-reaching consequences of the BRI are yet to be felt. Yet in view of the significant resources invested by China in the flagship initiative and complicated geopolitical dynamics at play along the Belt and the Road, it is useful to assess the notable security risks and uncertainties. It is in this broader context that the paper zooms in on one of the world's most complex and unstable regions - the Middle East. The remainder of the article is organised as follows. Firstly, it underscores the importance of the Middle East for the BRI and China. The second section examines the manifold security problems in the Middle East and the extant regional security architecture therein. The ensuing section looks at China's major attempts to raise its regional profile and the main impediments it faces to stepping up strategic involvement in the area. The fourth part sketches out the possible implications of China's growing role in the Middle East for Europe's interests, coupled with a brief discussion on the possibility for Sino-European cooperation.

\section{Middle East and China}

Security in the Middle East is critical to the BRI and China at large. First, the Middle East is strategically situated at the juncture of the overland and maritime routes, thereby integral to the BRI. Substantively, infrastructure and energy projects at the heart of the BRI are mostly complex, capital-intensive, large-scale, and long-term. Meanwhile, oil fields are particularly liable to sabotage and attack, as they constitute a crucial source of revenue for extremist and terrorist groups (Cooper 2017). Without a secure milieu, such colossal projects are highly risky and problematic, as evidenced by the significant losses Chinese state enterprises sustained following Libya's descent into war (Jian and Méndez 2015).

Second, the Middle East sits on the world's largest proven conventional oil reserves and has been a major source of China's oil supply. Out of China's ten top crude oil suppliers, five are in the Middle East - Saudi Arabia, Iraq, Iran, Kuwait, and the United Arab Emirates (UAE), although the energy-hungry giant has slowly diversified oil supplies and increased imports from oil producers outside the region such as Russia ${ }^{1}$ and Angola (Chinese General Administration of Customs 2017). Beijing's heavy reliance, albeit at reduced levels, on fuels from the region leaves it very vulnerable to

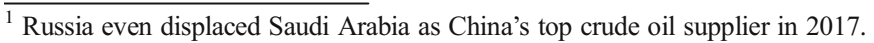


supply disruptions and price increases. Sustaining regional stability and ensuring supply security are thus important to China's energy security and economic development.

Third, building on robust energy ties, the Middle East has become an important trading partner for China and a fast-growing destination for Chinese investments. The total volume of trading in goods between China and the Middle East (including North Africa) increased from $\$ 3$ billion in 1992 to $\$ 245$ billion in $2015^{2}$ (World Bank 2017). According to the American Enterprise Institute (2017) - a Washington-based think tank - the value of Chinese cumulative investments and contracts (2005-2017) in Middle Eastern states had totaled $\$ 180$ billion, especially in Saudi Arabia (30.2 billion), Iran (24.3 billion), Egypt (22.2 billion), the UAE (20.4 billion), and Iraq (18.7 billion).

Furthermore, the region, notably strife-torn states, has become a fertile breeding ground for Islamic extremism and terrorism. The dramatic rise and spread of Islamic State of Iraq and Syria (ISIS) is a striking case in point. Terrorism in this hotspot can easily spill over to China's immediate neighbourhood, and more worryingly for Beijing, to the far-flung autonomous region of Xinjiang where most ethnic Uighurs dwell, some of which have been actively campaigning for Uighur independence and fought for the ISIS (Chaziza 2016). The sheer existence of Uighur militants and separatists sits uneasily with Beijing's perennial emphasis on tackling risks and maintaining stability, as Kerry Brown duly stressed in the introduction to this special issue, and might heighten the charged religio-ethnic tension in the restless province.

\section{Middle East: security situation and security architecture}

As an externally designated term, 'Middle East' carries with it strong European, and in particular, British and French, imprint. Different perspectives have frequently given rise to diverging ways to demarcate the area. Governments, policymakers, and academics have historically produced reasoned definitions that disagree with each other (Lewis 1998). Some hold that the Middle East as a geographic region includes three subregions: the Persian Gulf, the Levant, and the Maghreb; others contend that an adequate definition of the region should encompass the Arab League states, Iran, Israel, Turkey, or even Afghanistan and Pakistan (Jones 2009). For the sake of clarity, this article focuses primarily on the countries situated along the Belt and the Road and touches where appropriate on the states in the Maghreb. As regards security, the study interprets it in a rather restricted sense and looks mostly at factors that have an impact on stability and peace.

\section{Precarious security dynamics: conflicts and terrorism}

The Middle East, marred by manifold security problems, is chronically unstable and conflict-prone. First, it is a region rife with violent and prolonged conflicts. Among others, the intractable dispute between Israelis and Palestinians (by extension, the Arab world) culminated in several major Israeli-Arab wars. While Israel reconciled with Egypt (1979) and Jordan (1994), the Israeli-Palestinian conflict has been going in

\footnotetext{
$\overline{2 \text { The trade volume fell by } 14 \% \text { in }} 2016$ to $\$ 211$ billion.
} 
vicious circles for decades with no prospect of reaching a viable, sustained peace agreement. This is even more striking considering the long involvement of the Quartet - the primary international mechanism for mediating the Israeli-Palestinian peace talks comprised of the United States (US), the European Union (EU), the United Nations (UN), and Russia. A recent report (UN 2016) by the Quartet identified three main hurdles to a viable two-state solution: the spiral of violence and retaliatory attacks in both directions, the expansion of Israeli settlements in West Bank, the fragmentation of Palestinian authority between Fatah and Hamas. While the last issue seems to have somewhat progressed in view of the reconciliation deal reached between the two Palestinian factions in October 2017, the first two problems are likely to be complicated by the decision of President Trump to recognise Jerusalem as Israeli capital, threatening to derail the entire peace process premised on a two-state solution (Landler 2017). In addition to this festering dispute, open conflicts including the Iran-Iraq war (19801988), Gulf war (1991), Iraq war (2003), Israel-Hezbollah war (2006), and protracted civil wars in Libya, Syria, and Yemen have also contributed to volatile security dynamics in the strife-prone area. Relatedly, the region-wide fault line between Shia and Sunni (not to mention the tension inside the Sunni Arab world), the ongoing regional contest for influence between major regional powers (Gause 2017), and the geopolitical gambits of outside players have all played a role in compounding the security situation. A prime example in this regard is the Syrian conflict. It has over time cascaded into a proxy war for the Shia-Sunni divide, fight for sphere of influence, and US-Russian great-power game.

Second, ill-fated regime changes and drawn-out conflicts have left power vacuums, allowing Islamic extremists and terrorists to rapidly expand operating space. Seven years after the Arab Spring, it is ever clearer that the much-hyped popular upheavals have failed to fundamentally transform existing state and societal structures. Since the overthrow of Ben Ali and Mubarak, Tunisia and Egypt have seen several changes of government. But the new leaderships, either democratically elected or authoritarian, have proved incapable of grappling with the problems and challenges ensuing from uprisings. Syria has been devastated by a prolonged armed conflict since 2011, resulting in massive casualties, internal displacement, and refugee outflow. The issue with Kurdish nationalism is likely to exacerbate the perils of the post-ISIS Syria and Middle East at large. In Libya, a cohesive post-Gadhafi government has never really materialised, and the state is still stalemated between warring factions clamouring for legitimacy and control over oil infrastructure (Lacher 2017). Iraq, albeit with a functioning government, remains wobbly due to terrorist threat, systemic corruption, and deep-seated ethnic tension between Shia, Sunni, and Kurdish communities (O'Driscoll 2017). Yemen has been engulfed in a civil war since 2015, pitting government forces supported by Saudi Arabia against Houthi militias backed by Iran. These war-torn countries have effectively become failed or failing states unable to fulfil basic functions of statehood. Terrorist groups have been quick to capitalise on the vacuum of authority and considerably expanded their operations. According to the Global Terrorism Database, the Middle East and North Africa experienced a total of 6088 terrorist attacks in 2016 and accounted for almost half of the total number of attacks committed worldwide; ISIS alone carried out more than 1400 attacks leading to 11,700 deaths (Miller 2017). While the US-led international coalition has defeated the ISIS for now, lingering risk of its return and continual existence of other jihadi groups such as al-Qaeda, 
coupled with (re-)emerging contradictions and conflicts between major regional and world powers in the wake of the anti-ISIS war, lay bare the precarity and complexity of regional security situation (Malley 2017).

Third, threats to stability and security in the Middle East are hybrid and intertwined. Quite often, conflicts in the area have many dimensions - local, national, regional, or even global, stemming from frictions between religions, religious sects, ethnic groups, and national authorities. Traditional security risks are entwined with non-traditional security issues. For instance, a key point of contention between Israelis and Palestinians is over water rights (Lowi 1993). The rise of ISIS, as noted earlier, is in part due to the protracted war in Syria and the failed state-building process in Iraq. Syrian civil war has hitherto been one of the most important drivers of refugee outflows, exerting major strains on neighbouring Lebanon, Jordan, and Turkey, and resulting in an unprecedented crisis in Europe. Endemic security risks and problems, traditional and nontraditional alike, are entangled to such an extent that tackling them requires both short-term crisis responses and long-term structural measures, from both endogenous and exogenous forces.

\section{Existing security architecture: fragmented and inadequate}

Despite prominent security needs, the Middle East currently has no overarching regionwide institutional structures for managing and resolving inter-state (or intra-state) disagreements, tensions, and conflicts. A pan-regional approach to security (e.g. 'Middle East OSCE') proposed by regional leaders in the 1990s and 2000s was never tried out due to Israeli-Arab confrontations, hostilities to Iran's revolutionary government, and concerns over the loss of sovereignty (Jones 2009). For now, Middle Eastern security architecture is mainly comprised of regional organisations represented by the Arab League and the Gulf Cooperation Council (GCC), and the involvement of major outside powers.

\section{Regional organisations}

The Arab League is one of the most influential organisations across the Middle East. It was established in 1945 in Cairo reactive to concerns about incipient post-war divisions and bitter resistance to the emergence of Zionism in Palestine (Hourani 1947). It was once touted as a symbol of unity between Arab states in their fight for independence against British and French imperialism. However, its credibility as a security-military alliance was seriously undermined when several members (e.g. Egypt in 1956, Kuwait in 1990, Iraq in 2003) were invaded without triggering the collective security mechanism. The 22-member League, albeit long denigrated as a disunited and toothless organisation, gained somewhat renewed relevance in the immediate wake of the Arab Spring (Maddy-Weitzman 2012). It called on the UN to impose a no-fly zone over Libya and take action to protect civilians, effectively providing legitimacy for the ensuing NATO-led military intervention (Daalder and Stavridis 2012). It also suspended Syrian membership and called for al-Assad to step down (Masters and Sergie 2014). More recently in 2015, faced with widespread threats of terrorism across the region, heads of the League member states agreed to create on a voluntary basis a 40,000-strong joint Arab force. Yet Saudi Arabia, supported by other Gulf Arab states, has indefinitely postponed the plan (Gaub 2015). In general, sovereignty-cherishing 
members of the League have been leery of security cooperation that might encroach on their sovereignty (Dakhlallah 2012). Another feature worth pointing out is that the Arab League, as the name indicates, is exclusive of non-Arab states. As such, major regional powers Iran, Israel, and Turkey are not even members.

The six-nation GCC, created in 1981 with the immediate purpose of countering the spill-over effects of the Iran-Iraq war and Iranian-inspired Islamic fundamentalism (Kechichian 1985), brings together all the Arab states in the Persian Gulf except Iraq. Since 1981, the GCC has indeed achieved a relatively high level of cooperation on the economic, political, and military fronts. In terms of security and defence, the 2000 Gulf Security Agreement not only prepared the ground for later development of a joint force but, more importantly, marked the GCC's transition from defence coordination to collective defence, at least on paper (Saidy 2014). The number of troops, already exceeding 30,000 by 2014 , is slated to increase further in view of the GCC's 2013 summit decision to set up a unified military command with a force of 100,000, as well as growing threats from a potentially nuclear-capable Iran and terrorist organisations (Alajmi 2015). Notwithstanding clear progress in developing joint-defence capability, security-military cooperation among the GCC states has been hamstrung by technical limitations, internal rifts, and diverging threat perceptions, particularly vis-à-vis Iran (Kahan 2016).

\section{Major outside powers}

Another non-negligible layer of security mechanism involves outside powers. As a conflict-ridden area and yet of strategic importance, the Middle East has witnessed constant foreign interventions. Being the main security guarantor in the area with a constellation of regional partners and military bases, Washington has maintained longterm interest and enjoyed decades-long unchallenged primacy therein. During the Cold War, the Middle East was deemed crucial to a 'holy trinity' of American interests: oil, Israel, and countering the creeping influence of Soviet Union and communism (Hudson 2013). In the 1990s, the US successively inked a 'Defence Cooperation Agreement' with Bahrain (1991), Kuwait (1991), Qatar (1992), and the UAE (1994) (aside from the 'Mutual Defence Assistance Agreement' concluded with Saudi Arabia in 1951 and the 'Military Cooperation Agreement' with Oman in 1980). It enjoys a special relationship with Israel and offers significant military and economic aid to Egypt (Sharp 2017). Besides, protracted military interventions and failed state-building efforts in Iraq and Afghanistan have witnessed the US bogged down in the Middle East. Despite the much-hyped pivoting/rebalancing strategy since 2011 to boost engagement in the AsiaPacific, Washington remains (over-)invested in the affairs of the troubled region. Its prominent role in the Syrian crisis and anti-ISIS campaign is a case in point. ${ }^{3}$ Facing rising threats to regional security, the US has followed a strategy of 'surrogating' warfare (Krieg 2016) through, for instance, its efforts to 'lead from behind' in Libya, support opposition forces in Syria, and empower Kurdish and Iraqi fighters in the campaign against ISIS. Nevertheless, it is no longer inconceivable that Washington will eventually end its decades-long military commitment in the Middle East, since the costs of preventing oil disruptions with military might are becoming increasingly unpalatable (Glaser and Kelanic 2017).

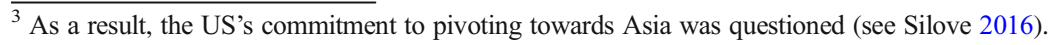


The EU is another major actor in the Middle East. In contrast with the US, the Union is the world's largest donor of non-military assistance, and its security footprint in the region has mostly been limited to conflict mediation (Müller 2013). It popularised the two-state solution to the Israel-Palestinian conflict and acted as the principal driver behind the Quartet (Tocci 2013). Leveraging cooperation between the EU3 (France, Germany, UK), the EU also played a prominent mediating role in the negotiations between Iran and P5+1 (EU3, US, Russia, China) (Schmitt 2017), which culminated in the Joint Comprehensive Plan of Action in July 2015 wherein Tehran agreed to scale back its nuclear activities in exchange for the lifting of some crippling sanctions. However, Europe has been widely criticised for its failure to recalibrate its policy towards the region in the wake of the Arab Spring, and its inaction (and lack of a clear position) vis-à-vis the Syrian, Yemeni, and Israel-Palestinian conflicts (Dempsey 2017).

As for Russia, its intervention in Syria, with an ostensible aim to combat the ISIS, is an illustrative case of its foray into the Middle East in the face of an over-stretched and more introspective US. To protect its sole Mediterranean military base at Tartus on the Syrian coast and upgrade its role across the region, Moscow has supported the al-Assad government by vetoing UN Security Council resolutions, deploying troops and conducting airstrikes. This has not only offered a shop-window to showcase Russian military capabilities and put Moscow on a par with Washington, but also tipped the power balance in favour of President al-Assad and ensured the survival of the regime (Stent 2016). As an indispensable player now in the Syrian conflict, Russia holds great sway on the peace negotiations and post-war reconstruction.

Up till now, there is little doubt that the performance of regional organisations and external interventions, particularly in conflict situations, has been lacklustre. Regional organisations are often divided, exclusionist, and/or plagued by the disinclination of member states to strengthen collective security at the expense of sovereignty. Foreign powers have either complicated the situation by siding with a party and turning the conflict into a proxy war or are reluctant to get deeply involved. As a result, there seems to be no viable solution to the region's protracted crises and conflicts.

\section{China pivoting towards the Middle East: how ambitious, how inhibited?}

As noted earlier, China has now extensive energy and commercial interests in the Middle East, which will probably grow further following the implementation of the BRI. Also, there has been a persistent call in the international community for China to stop freeriding (or cheap-riding) and assume due responsibilities expected of a major power (Harding 2015), not least in the Middle East. To safeguard its growing interests and pursue an enhanced international status, Beijing has over time opted for a multipronged approach, leveraging diverse tools of statecraft and expanding regional involvement beyond economic activism (Jin 2017). It attempts to pose itself as a constructive alternative to other long-term stakeholders, most notably the US. As Xi (2016) encapsulated in his speech at the Arab League headquarters, 'instead of looking for a proxy in the Middle East, we promote peace talks; instead of seeking any sphere of influence, we call on all parties to join the circle of friends for the Belt and Road Initiative; instead of attempting to fill the vacuum, we build a cooperative partnership network for win-win outcomes'. 


\section{Raising political and security profile}

Apart from continuing to expand economic activities, China has made efforts to raise its political and security profile throughout the Middle East in recent years. Since 2010, it has been conducting an annual ministerial-level dialogue with the six-state GCC to discuss issues of strategic significance to regional and global security. It has committed to building a 'Comprehensive Strategic Partnership' with Egypt (2014), Iran (2016), and Saudi Arabia (2016), and a 'Strategic Partnership' with the UAE (2012), Jordan (2015), and Qatar (2014). In January 2016 Beijing released its Arab Policy Paper, first of its kind issued for the Middle East. This was shortly followed by President Xi's highlevel state visit to Saudi Arabia, Egypt, and Iran.

In parallel, China has been trying to act as a mediator in conflict situations. The US and lately Russia have sided with a warring party, effectively rendering both powers incapable of acting as an impartial broker. On the other hand, China, owing in part to its generally perceived neutrality, has built a reputation of 'enemy of none and common friend to all' (Scobell and Nader 2016). It has working relations and open communications with all key regional actors and disputing parties. At the 5th Forum on Asia and Middle East in 2016, China's current Special Envoy to the Middle East Gong Xiaosheng argued that the most distinctive feature of China's role in the Middle East is impartiality (Yu 2016). As such, Beijing can in principle become a viable alternative, and indeed, it has stepped up efforts in this regard. For instance, it was one of the six powers involved in negotiating and monitoring the Iran nuclear deal. Chinese Special Envoy to the Middle East (in place since 2002) has been working mainly on the Israeli-Palestinian issue. Beijing outlined a five-point peace proposal in 2013 (updated as a four-point plan in 2017) and proposed a China-Israel-Palestine trilateral dialogue in 2017 (Xinhua 2017) in the hopes of playing a more prominent role. In March 2016, it appointed Xie Xiaoyan - a former ambassador to Iran - as its first Special Envoy to Syria.

Furthermore, China has sought to become more visible in terms of military presence. Since 2008, Chinese People's Liberation Army Navy has participated in anti-piracy and escort missions in the Gulf of Aden. In 2015, China deployed 700 combat troops to South Sudan as part of a UN-sanctioned peacekeeping mission, pledged 8000 troops to the UN peacekeeping standby force, and passed a law legalising overseas anti-terrorism operations, all marking a retreat from its claimed position of non-intervention (Duchâtel et al. 2016). In 2017, China inaugurated its first permanent overseas military base in Djibouti - a Horn of Africa country that occupies a strategic position next to the Bal alMandab Strait and the Middle East. The naval support facility will likely have the capability to support China's anti-piracy patrols, intelligence collection, non-combat evacuation operations, peacekeeping, and counter-terrorism missions in the wider region (Downs et al. 2017).

Taken together, these attempts indeed signal a strong will of China to boost politicalsecurity footprint and contribute more to the provision of security in the troubled area. That said, the commitment of Beijing to upgrading political relationships with regional actors is yet to translate into concrete follow-ups, and the effectiveness of its eclectic mix of measured advances on the security front is, to say the least, dubious. In general, China prefers to take a back seat to the UN-led diplomatic efforts in conflict resolution (as in Syria) and refrains from intensively investing security-strategic resources (Evron 2017), a role termed by some as 'quasi-mediation diplomacy' (Sun and Zoubir 2017). 
Its special envoys and peace plans have not resulted in any substantial settlement. So far, China's engagement in the Middle East has been overwhelmingly economic and energy-driven and will likely remain so for some time to come given the ' $1+2+3$ ' guideline outlined in China's Arab Policy Paper. Specifically, the guideline for ChinaArab cooperation identifies energy as one priority, infrastructure and trade-investment promotion as two key areas, aerospace, nuclear, and renewable energy as three breakthroughs (Xinhua 2016). It attests to Beijing's focus on energy-economic links and reluctance to get deeply involved on a political-security level.

\section{Limitations and risks}

Even if Beijing does decide to boost security presence in the region, it will face substantial limitations and risks. First, overall China's footprint in global security remains selective and piecemeal. Its role as a global security actor has been tempered by a perennial emphasis on sovereignty and non-intervention, as well as continual fixation on national security and development. Facing the growing need to protect its interests and citizens abroad, China has indeed departed from its longstanding handsoff posture in some cases (as in Libya and South Sudan). However, these cases are often UN-led collective action wherein China can avoid openly taking sides, thus allowing it to still claim broad adherence to the principle of non-intervention.

Even with its increasingly proactive multi-faceted foreign policy, Beijing still prioritises its relationships with major powers and periphery states: its strategic narrative of 'new type of great-power relations' highlights the importance of the US, Europe (i.e. France, Germany, UK), Japan, and Russia; BRI was initially proposed for China's immediate neighbourhood (Zeng 2017). Beijing's focus on maintaining peace and security in its periphery, above all the Asia-Pacific and Central Asia, is evidenced by the enormous wherewithal China has expended to manage the nuclear crises in the Korean Peninsula and maritime disputes in the South China Sea, as well as by its vested interests in the Asia-centric security mechanisms exemplified by the ASEAN Regional Forum, the East Asia Summit, the Shanghai Cooperation Organisation, and the Conference on Interaction and Confidence-Building Measures.

By contrast, China's strategic involvement in Middle Eastern security, while expanding, is circumscribed in scope and depth. Driven by an overriding consideration to secure energy, China deals with regional actors both bilaterally and multilaterally, but with scant attention to security. Bilateral ties between China and oil-producing countries have been predominated by energy; discussions in the sole multilateral settingChina-Arab States Cooperation Forum ${ }^{4}$ - have focused mostly on economic, social, and cultural issues, with little progress made on the political-strategic front (Jalal 2014). Even with the BRI, the situation is not very likely to change, since the initiative was primarily conceived as a development framework centring on infrastructure and connectivity, and does not contain a salient security dimension. This implies that China intends to advance economic interests and secure oil supply by investing in infrastructure and energy projects - in line with the ' $1+2+3$ ' cooperation guideline, all the while keeping a low security profile.

\footnotetext{
${ }^{4}$ Started in 2004, it consists of Ministerial Conference, Senior Official Committee Meeting, and other sectorspecific mechanisms.
} 
Second, it is possible that China's greater involvement in Middle Eastern security will put Washington and Beijing at odds, causing friction and intensifying Sino-US competition. As a Chinese idiom says, a mountain cannot accommodate two tigers. The US remains anchored in the Middle East despite efforts to extricate itself in recent years (Krieg 2016). It guards carefully the (perceived) Pax Americana and is understandably wary of China's growing presence, especially in the security domain (Scobell and Nader 2016). For instance, Washington has been persistent in excluding Beijing from the Quartet (Tian 2016). More recently, China's naval base in Djibouti has caused concern among US officials. As the US ambassador to Djibouti said, it 'will be a challenge for all involved' to manage the coexistence of an American and a Chinese base in the same country (Manson 2016). It is thus conceivable that intensified USChina rivalry or, worse, a pernicious downward spiralling of bilateral relations may ensure from China's rising ambitions and growing profile in a region where the US hegemony has remained uncontested for decades.

\section{China's growing role in the Middle East: what's in it for Europe?}

Since 2003, the EU and China have been developing a 'comprehensive strategic partnership', designed to elevate bilateral relations beyond economic ties to political and even security domains (Christiansen and Maher 2017). It has been subsequently substantiated by an increasing number of institutionalised dialogues, working groups, and specific projects encompassing an array of areas (Smith 2016). Still, EU-China relations are based mostly on trade and investment, and thus far, there has been little strategic coordination (Maher 2016). Going beyond bilateral relations, the EU, as laid out in the 2016 Global Strategy, prioritises in its external action the aims to support the resilience of states and societies, to facilitate the resolution of conflicts and crises, and to foster the formation of cooperative regional orders; specific to the Middle East, it considers 'solving conflicts and promoting development and human rights' as essential to tackling other issues like terrorism, migration, and poverty (EU 2016). On the Chinese side, Beijing is poised to advance its interests and have a larger presence in the Middle East as the BRI unfolds. In this light, it is useful to evaluate on a case-bycase basis the compatibility_ or lack thereof — between European and Chinese interests in the region and the prospect of further EU-China cooperation.

First, there is little common ground between Europe and China in terms of normative preference. As a self-proclaimed normative power, the EU has been striving, albeit with a chequered record, to promote human rights, democracy, and rule of law beyond European borders, including in the Middle East. China, on the other hand, is not remotely interested in promoting these values in its foreign policy. Espousing a sovereignty-bound approach, Beijing asserts that the issue of human rights falls squarely under the domestic jurisdiction and therefore third countries shall not interfere (Pan 2010). Second, European and Chinese efforts can be cooperative and complementary in promoting development in the region and beyond. The EU tends to invest more in the 'software' of social infrastructure, whereas China has been more interested in building the 'hardware' of physical infrastructure as the foundation for development (Yang 2017). Placed at the core of the BRI, development based on infrastructure links can be a field where Europe and China find synergy and cooperate on a pragmatic 
level, as argued in several other contributions to this special issue. Third, in addition to allegedly fostering peace by development (e.g. BRI can be a tension-reduction mechanism), China has, as discussed above, shown a growing interest in playing a role, however marginal that might have been, in mediating conflicts and countering piracy and terrorism. Meanwhile, Europe has been overwhelmed by a massive influx of refugees from war-torn states such as Afghanistan, Libya, Iraq, and Syria. Consequently, the EU and member states are hard-pressed to bring a swift end to protracted conflicts and stabilise the immediate periphery through a diverse toolkit including diplomacy and military campaigns. Indeed, shared Europe-China interests in a stable Middle East offer new leads for effective cooperation, as demonstrated by the Iran nuclear deal and the EU-China naval counter-piracy cooperation in the Gulf of Aden. This will potentially put the 'strategic' partnership on a more solid footing.

\section{Concluding remarks}

China is rising (or has risen in many aspects) to become a global great power (Breslin 2017). But for now, China has shown limited inclination to strengthen its strategic engagement in the Middle East - seen as an area of no paramount concern and a graveyard for great powers. Its modus vivendi therein is highly pragmatic and selective, mixing a dominant focus on energy and economic interests with a strong aversion to wading knee-deep on a security level. Its 'quasi-mediation diplomacy' aims to safeguard its commercial and political gains rather than defending core security and strategic interests (Sun and Zoubir 2017). Yet, the region's problematic security structure and worsening security situation, coupled with the diminishing will of a more introspective US for security-military engagement, have thrown wide open the question of what needs to be done to stop the incendiary region from descending into total chaos. At the same time, stakes are higher than ever for Beijing, given the imperative to ensure the security of energy supply and a growing number of BRI-related projects, protect China's economic interests and citizens, and contain the spill-over of terrorism on stability in its periphery and Xinjiang.

Herein lies the great dilemma for China: whether to step up and play a more substantial role in Middle Eastern security to better protect China's economic gains and extend strategic influence, or to continue exercising relative caution and remain largely disengaged on the security front to avoid getting bogged down in the quagmire and creating an undue burden for itself. Just as Walter Lippmann (1943: 9-10) said decades earlier, 'without the controlling principle that the nation must maintain its objectives and its power in equilibrium, its purposes within its means and its means equal to its purposes, its commitments related to its resources and its resources adequate to its commitments, it is impossible to think at all about foreign affairs'. If anything, the US's dragged-out military operations and evident failures in Iraq and Afghanistan should weigh on any outside actor intent on getting strategically involved in the Middle East. With respect to economic clout, military capability, soft power, and the ability to leverage these resources to exert power, Beijing is undoubtedly interior to Washington. Also, it will be exceedingly challenging for China to redouble security efforts without undermining its precariously balanced relationship with a plethora of competing powers and its ostensibly neutral position on a number of contested issues, let alone 
run the risk of antagonising the big elephant in the room-US. Hence, a huge leap into the unknown with possibly costly consequences is unlikely for the foreseeable future. That said, the BRI is both a strategic opportunity and an urgent call for the fast-rising power to recalibrate its Middle East strategy to the evolving regional and global environment. With all the cost-benefit calculations in mind, it would make sense that China seeks to step up its game in areas that are conductive to stabilising the region and yet do not entail investing intensively strategic resources and taking sides publicly (e.g. infrastructure development and UN-sanctioned conflict resolution). This will offer reasonable prospect of further Sino-European cooperation.

\section{References}

Alajmi ZM (2015) Gulf military cooperation: tangible gains or limited results? Al Jazeera, 31 March, http://studies.aljazeera.net/en/dossiers/2015/03/201533164429153675.html

American Enterprise Institute (2017) China global investment tracker, https://www.aei.org/china-globalinvestment-tracker

Breslin S (2017) Still rising or risen (or both)? Why and how China matters. Pac Rev 30(6):870-884

Chaziza M (2016) China's Middle East policy: the ISIS factor. Middle East Policy 23(1):25-33

Cheng LK (2016) Three questions on China's "Belt and Road Initiative". China Econ Rev 40:309-313

Chinese General Administration of Customs (2017) Customs statistics (in Chinese), http://www. chinacustomsstat.com/customsstat/

Chinese National Development and Reform Commission (2017) Yidaiyilu jianshe qude xinjinzhan maishang xintaijie [BRI has made new progress], 18 August, http://www.ndrc.gov.cn/xwzx/xwfb/201708 /t20170818 858077.html

Chinese State Council (2015) Action plan on the Belt and Road Initiative, 28 March, Beijing, http://english.gov.cn/archive/publications/2015/03/30/content 281475080249035.htm

Christiansen T, Maher R (2017) The rise of China — challenges and opportunities for the European Union. Asia-Europe Journal 15(2):121-131

Clarke M (2017) Belt and Road Initiative: China’s new grand strategy? Asia Policy 24:71-79

Cooper WH (2017) The dark side of the economy: a comparative analysis of the Islamic State's revenue streams. J Terror Res 8(1):34-42

Daalder IH, Stavridis JG (2012) NATO's victory in Libya: the right way to run an intervention. Foreign Aff 91(2):2-7

Dakhlallah F (2012) The League of Arab States and regional security: towards an Arab security community? Br J Middle Eastern Stud 39(3):393-412

Dempsey J (2017) Judy asks: is Europe powerless in the Middle East? Carnegie Europe, 5 April, http://carnegieeurope.eu/strategiceurope/68562

Downs E, Becker J, and DeGategno P (2017) China's military support facility in Djibouti: the economic and security dimensions of China's first overseas base. Center for Naval Analyses, Arlington, US

Duchâtel M, Gowan R, Rapnouil ML (2016) Into Africa: China's global security shift. European Council on Foreign Relations, London

European Union (EU) (2016) A global strategy for the European Union's foreign and security policy, 28 June, https:/europa.eu/globalstrategy/en/global-strategy-foreign-and-security-policy-european-union

Evron Y (2017) China's diplomatic initiatives in the Middle East: the quest for a great-power role in the region. Int Relat 31(2):125-144

Ferdinand P (2016) Westward ho - the China dream and 'One Belt, One Road': Chinese foreign policy under Xi Jinping. Int Aff 92(4):941-957

Gaub F (2015) Stuck in the barracks: the joint Arab force. Brief 31, European Union Institute for Security Studies, Paris

Gause FG (2017) Ideologies, alignments, and underbalancing in the new Middle East Cold War. PS: Polit Sci Polit 50(3):672-675

Glaser CL, Kelanic RA (2017) Getting out of the Gulf: oil and US military strategy. Foreign Aff 96(1):122-131

Harding H (2015) Has US China policy failed? Wash Q 38(3):95-122 
Hourani CA (1947) The Arab League in perspective. Middle East J 1(2):125-136

Huang YP (2016) Understanding China's Belt \& Road Initiative: motivation, framework and assessment. China Econ Rev 40:314-321

Hudson MC (2013) Geopolitical shifts: Asia rising, America declining in the Middle East? Contemp Arab Aff 6(3):458-466

Jalal MN (2014) The China-Arab States Cooperation Forum: achievements, challenges and prospects. J Middle East Islam Stud 8(2):1-21

Jian LB, Méndez A (2015) Change and continuity in Chinese foreign policy: China's engagement in the Libyan Civil War as a case. LSE Working Paper Series 5, LSE Global South Unit, London

Jin LX (2017) China's role in the Middle East: current debates and future trends. China Q Int Strateg Stud 3(01):39-55

Jones P (2009) Structuring Middle East security. Survival 51(6):105-122

Kahan JH (2016) Security assurances for the Gulf states: a bearable burden? Middle East Policy 23(3):30-38

Kechichian JA (1985) The Gulf Cooperation Council: search for security. Third World Q 7(4):853-881

Krieg A (2016) Externalizing the burden of war: the Obama Doctrine and US foreign policy in the Middle East. Int Aff 92(1):97-113

Lacher W (2017) Was Libya's collapse predictable? Survival 59(2):139-152

Landler M (2017) Trump recognizes Jerusalem as Israel's capital and orders U.S. embassy to move, The New York Times, 6 December, https://www.nytimes.com/2017/12/06/world/middleeast/trump-jerusalemisrael-capital.html

Lewis B (1998) The multiple identities of the Middle East. Random House, New York

Lippmann W (1943) US foreign policy: shield of the republic. Little, Brown and Company, Boston

Lowi MR (1993) Bridging the divide: transboundary resource disputes and the case of West Bank water. Int Secur 18(1):113-138

Maddy-Weitzman B (2012) The Arab League comes alive. Middle East Q 19(3):71-78

Maher R (2016) The elusive EU-China strategic partnership. Int Aff 92(4):959-976

Malley R (2017) The war after the war, Foreign Policy, 10 July, http://foreignpolicy.com/2017/07/10/whatcomes-after-isis-islamic-state-mosul-iraq-syria/\#malley

Manson K (2016) China military to set up first overseas base in Horn of Africa, Financial Times, 31 March, http://www.ft.com/cms/s/0/59ad20d6-f74b-11e5-803c-d27c7117d132.html

Masters J, Sergie MA (2014) The Arab league. Council on Foreign Relations, New York

Miller E (2017) Overview: terrorism in 2016. START, College Park

Müller P (2013) Europe's foreign policy and the Middle East peace process: the construction of EU actorness in conflict resolution. Perspect Eur Polit Soc 14(1):20-35

O’Driscoll D (2017) Autonomy impaired: centralisation, authoritarianism and the failing Iraqi state. Ethnopolitics 16(4):315-332

Pan ZQ (2010) Managing the conceptual gap on sovereignty in China-EU relations. Asia Europe Journal 8(2): $227-243$

Rolland N (2017) China's "Belt and Road Initiative": underwhelming or game-changer? Wash Q 40(1):127-142

Saidy B (2014) GCC's defense cooperation: moving towards unity. Foreign Policy Research Institute, Philadelphia

Schmitt EM (2017) Between European and national role conceptions - the EU3 initiative regarding the Iranian nuclear programme. Eur Secur 26(2):253-272

Scobell A, Nader A (2016) China in the Middle East: the wary dragon. RAND, Santa Monica https://www.rand.org/pubs/research_reports/RR1229.html

Sharp JM (2017) Egypt: background and US relations. Congressional Research Service, Washington D.C https://fas.org/sgp/crs/mideast/RL33003.pdf

Silove N (2016) The Pivot before the Pivot: US strategy to preserve the power balance in Asia. Int Secur 40(4):45-88

Smith M (2016) EU diplomacy and the EU-China strategic relationship: framing, negotiation and management. Camb Rev Int Aff 29(1):78-98

Stent A (2016) Putin's power play in Syria: how to respond to Russia's intervention. Foreign Aff 95(1):106-113

Sun D, Zoubir Y (2017) China's participation in conflict resolution in the Middle East and North Africa: a case of quasi-mediation diplomacy? J Contemp China 27:224-243. https://doi.org/10.1080 /10670564.2018.1389019

Tian WL (2016) Yidai yilu yu zhongguo de zhongdong zhanlüe [One Belt One Road and China's Middle East strategy] . Xiya feizhou [West Asia and North Africa] 2:127-145 
Tocci N (2013) The Middle East Quartet and (in)effective multilateralism. Middle East J 67(1):28-43

United Nations (UN) (2016) Report of the Middle East Quartet. 1 July, http://www.un.org/News/dh/infocus/middle east/Report-of-the-Middle-East-Quartet.pdf

Wang Y (2016) Offensive for defensive: the Belt and Road Initiative and China's new grand strategy. Pac Rev 29(3):455-463

World Bank (2017) China product exports and imports, http://wits.worldbank.org

Xi JP (2016) Speech at the Arab League headquarters, 21 January, http:/www.chinadaily.com.cn/world/2016 xivisitmiddleeast/2016-01/22/content 23191229.htm

Xi JP (2017) Speech at opening of Belt and Road forum, 14 May, http://www.xinhuanet.com/english/2017-05 /14/c 136282982.htm

Xinhua (2016) China's Arab Policy Paper, 13 January, http://news.xinhuanet.com/english/china/2016-01/13 /c_135006619.htm

Xinhua (2017) China proposes trilateral dialogue with Palestine, Israel, 18 July, http://www.xinhuanet. com/english/2017-07/18/c 136453600.htm

Yang H (2017) The EU and China: mismatched partners on development? In: Ujvari B (ed) EU-China Cooperation in Global Governance: going beyond the conceptual gap. Egmont, Brussels, pp 5-10

Yu XQ (2016) Zhongguo zai zhongdong xin zitai yin guanzhu [China's new posture in the Middle East attracts attention], The Paper, 25 September, http://www.thepaper.cn/www/v3/jsp/newsDetail_forward_1533894

Yu H (2017) Motivation behind China's 'One Belt, One Road' Initiatives and Establishment of the Asian Infrastructure Investment Bank. J Contemp China 26(105):353-368

Zeng JH (2017) Does Europe matter? The role of Europe in Chinese narratives of 'One Belt One Road' and 'New Type of Great Power Relations'. J Common Mark Stud 55(5):1162-1176 